\title{
AN APPROACH TO REDUCE LOAD ON THE ACID LEACHING CIRCUIT OF THE COMMERCIAL URANIUM RECOVERY PLANT AT JADUGUDA, INDIA
}

\author{
G.V. RAO * and S. PRAKASH \\ Regional Research Laboratory, Bhubaneswar 751013, Orissa, India
}

(Received 13 November 1997; Accepted 9 January 1998)

The commercial uranium recovery plant at Jaduguda, Bihar, India, currently treats around 900 tonnes of ore per day from the Jaduguda mine, containing around $0.05 \%$ $\mathrm{U}_{3} \mathrm{O}_{8}$. Subsequent to removal of the sulphide minerals present in the ore by flotation, nearly $95 \%$ of the tailings are being treated in the acid leaching circuit to recover the uranium values. Laboratory investigations on the bulk flotation tailings revealed that around $63 \%$ of the uranium values are associated with feebly magnetic material of the tailings. The magnetic product obtained on wet high intensity magnetic separator gave rise to a product containing $0.1 \% \mathrm{U}_{3} \mathrm{O}_{8}$. The rest of the uranium values were found to get enriched to $0.15 \% \mathrm{U}_{3} \mathrm{O}_{8}$ in the $-20 \mu \mathrm{m}$ fraction of the non-magnetic material thereby giving scope to retrieve the uranium values by recovering the slimes. Necessary unit operations needed to be introduced in the plant flowsheet to reduce load on the acid leaching circuit of the commercial uranium recovery plant are discussed.

Keywords: Flotation tailings; Acid leaching; Magnetic separation; Uraninite

\section{INTRODUCTION}

At Jaduguda, Bihar, India, M/S Uranium Corporation of India Limited (UCIL) is operating uranium recovery plant by treating uranium present as uraninite mineral in the ore mainly from Jaduguda mine and also ore from adjoining Bhatin mine. The details about the mineral constituents and the typical assay [1] of the Jaduguda uranium ore is

\footnotetext{
*Corresponding author. E-mail: root@csrrlbhu.ren.nic.in.
} 
given in Tables I and II. The plant designed to treat around $1000 \mathrm{t} /$ day ore, is currently reported to be treating $800-900 \mathrm{t} /$ day, containing $0.046 \%-0.06 \% \mathrm{U}_{3} \mathrm{O}_{8}$, as per the flowsheet given in Fig. 1. The flowsheet essentially consists of comminution, classification, bulk flotation to recover sulphide minerals, thickening of the bulk flotation tailings, acid leaching, filtration, ion exchange followed by precipitation to recover the uranium as yellow cake. The ore is ground in presence of cresylic acid, light diesel oil, soda ash and classified to produce a classifier overflow containing around $65 \%$ passing $75 \mu \mathrm{m}$ size. This ground classifier overflow is processed in three banks of flotation cells to recover the $1 \%-2 \%$ sulfide minerals present in the ore as bulk concentrate in the by-product recovery plant. The bulk concentrate containing $\mathrm{Cu}, \mathrm{Ni}$ and $\mathrm{Mo}$ is further processed by differential flotation as per flowsheet given in Fig. 2 to recover $\mathrm{Cu}$ and $\mathrm{Mo}$ as saleable grade concentrates. However, nickel which gets enriched to around $14 \% \mathrm{Ni}$

TABLE I Typical mineralogical composition of the Jaduguda ore

\begin{tabular}{lc}
\hline Minerals & $W t \%$ \\
\hline Quartz & 63.0 \\
Chlorite-Biotite & 23.5 \\
Magnetite & 3.0 \\
Tourmaline & 3.5 \\
Apatite & 3.0 \\
${ }^{* * S u l f i d e s}$ & 1.5 \\
Ilmenite & 1.0 \\
Uranium and other minerals & 1.5 \\
\hline
\end{tabular}

** Chalcopyrite ( $\mathrm{Cu}$ mineral); Pentlandite, Bravoite, Millerite (Ni minerals); Molybdenite (Mo mineral)

TABLE II Typical chemical analysis of the Jaduguda uranium ore

\begin{tabular}{lc}
\hline $\mathrm{U}_{3} \mathrm{O}_{8}$ & {$[0.04-0.06 \%]$} \\
$\mathrm{Mo}, \mathrm{Ni}, \mathrm{Mo}$ & $\mathrm{Mo}-0.02-0.045 \%$ \\
& $\mathrm{Cu}-0.06-0.10 \%$ \\
$\mathrm{SiO}_{2}$ & $\mathrm{Ni}-0.08-0.12 \%$ \\
$\mathrm{FeO}$ & 67.2 \\
$\mathrm{Fe}_{2} \mathrm{O}_{3}$ & 6.4 \\
$\mathrm{Al}_{2} \mathrm{O}_{3}$ & 7.9 \\
$\mathrm{CaO}$ & 5.5 \\
$\mathrm{MgO}$ & 5.4 \\
$\mathrm{P}_{2} \mathrm{O}_{5}$ & 2.20 \\
$\mathrm{~S}$ & 1.40 \\
$\mathrm{TiO}_{2}$ & 0.80 \\
& 0.66 \\
\hline
\end{tabular}




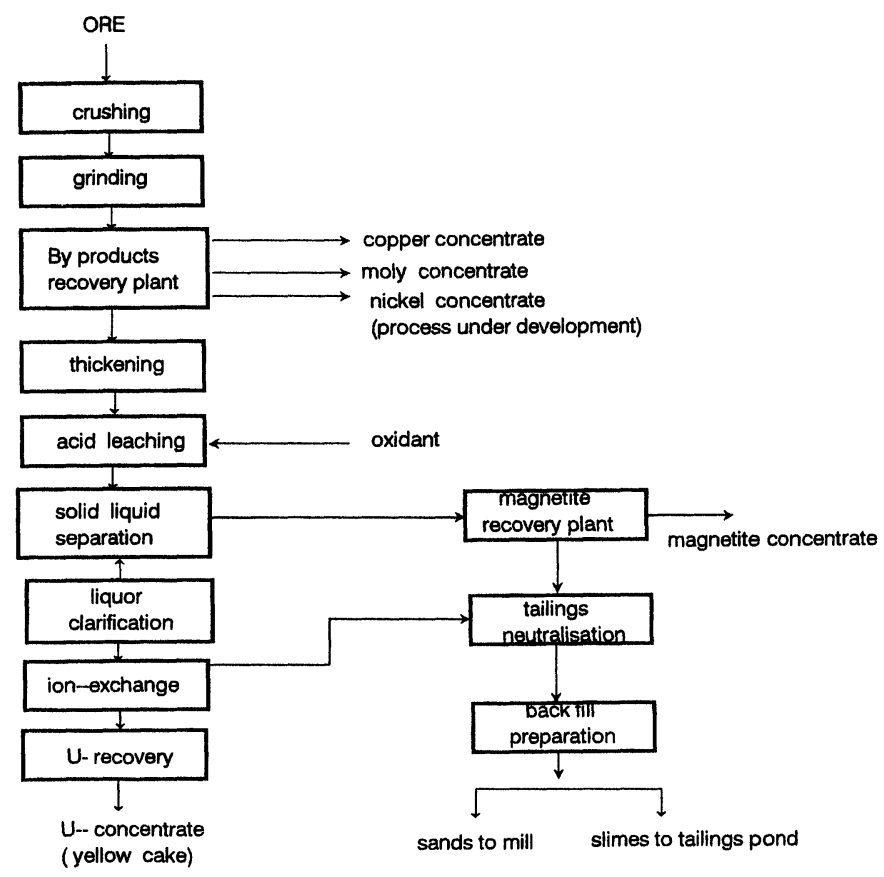

FIGURE 1 Flow sheet of Jaduguda Uranium recovery plant of UCIL.

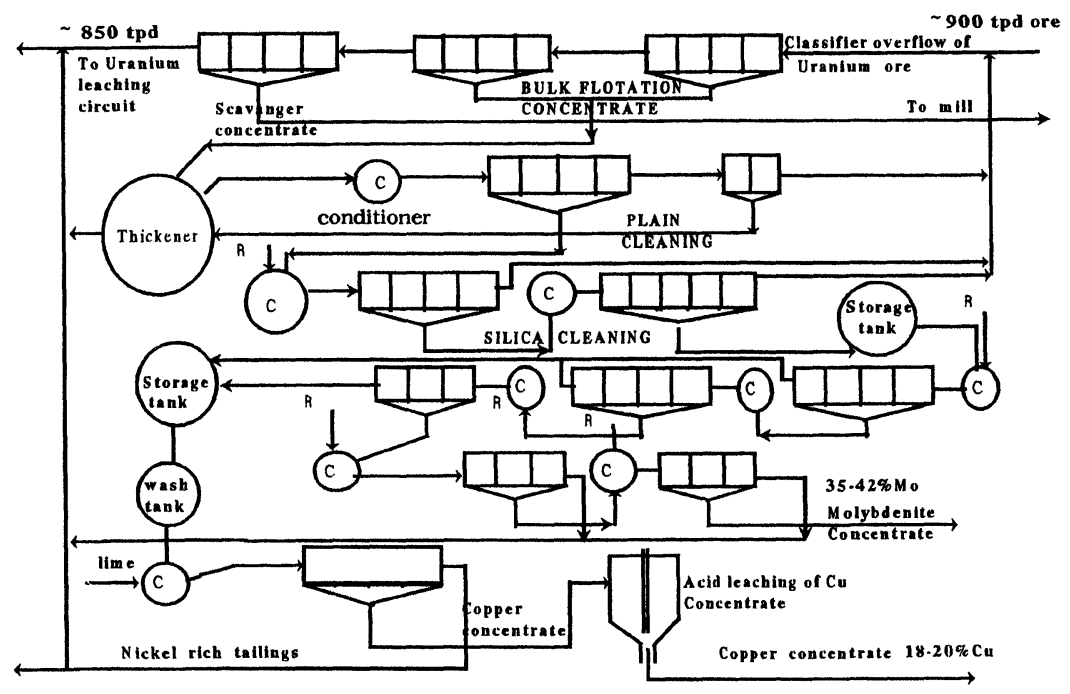

FIGURE 2 Byproduct recovery plant flow sheet at Jaduguda (operated by Uranium Corporation of India Ltd). 
after the $\mathrm{Cu}$ depletion, is currently not being recovered, due to nonavailability of a viable commercial process, and is dumped into the tailings pond.

UCIL has indicated that currently the recoveries of $\mathrm{Cu}, \mathrm{Ni}$ and $\mathrm{Mo}$ in the bulk concentrate are only around $60 \%, 25 \%$ and $55 \%$ respectively and sought assistance of the Regional Research Laboratory (RRL), Bhubaneswar to develop a viable flowsheet to recover all three metal values and also to simplify the flowsheet by incorporating the column flotation technology for the molybdenite recovery.

At the instance of UCIL, detailed studies were carried out at RRL on the classifier overflow samples as well as the bulk concentrate collected after the silicate cleaning stage of the flowsheet. During our endeavour to accomplish the desired modification and improvements in the existing flowsheet in the by-product recovery plant, it was also noticed that the magnetic fraction obtained at the magnetic intensity around $18,000 \mathrm{G}$ from the ore as well as the bulk flotation tailings were found to be enriched in $\mathrm{U}_{3} \mathrm{O}_{8}$ content.

This article describes the detailed laboratory investigations on the classifier overflow sample collected from the operating commercial plant, based on which a modified process could be arrived at to recover uranium from the bulk flotation tailings besides enrichment of the $\mathrm{U}_{3} \mathrm{O}_{8}$ content from the uranium ore of Jaduguda mine.

\section{SAMPLE AND CHARACTERISATION}

The ore from Jaduguda mine was ground in the plant by using the cresylic acid and light diesel oil in the grinding circuit, as per normal plant operating conditions, and the classifier overflow material was collected and sent to RRL as a slurry so that the submerged sample in water is not prone to rapid oxidation. The slurry received in various mild steel barrels was properly sampled and representative samples were drawn for the intended studies. A sub-sample was wet screened into various sieve fractions down to $53 \mu \mathrm{m}$ and analysed for $\mathrm{Cu}, \mathrm{Ni}$, $\mathrm{Mo}, \mathrm{Fe}$. The $\mathrm{U}_{3} \mathrm{O}_{8}$ content was analysed in the bulk sample (Table III). A sub-sample was also subjected to wet high intensity magnetic separation by using BOXMAG Laboratory magnetic separator and the products were analysed for $\mathrm{U}_{3} \mathrm{O}_{8}$ content (Table IV). 
TABLE III Size, $\mathrm{Cu}, \mathrm{Ni}, \mathrm{Fe}$ and Mo distribution in the classifier overflow sample

\begin{tabular}{|c|c|c|c|c|c|c|c|c|c|}
\hline \multirow[t]{2}{*}{ Size $(\mu \mathrm{m})$} & \multirow[t]{2}{*}{$W t \%$} & \multicolumn{5}{|c|}{ Assay (\%) } & \multicolumn{3}{|c|}{ Cumulative distribution $(\%)$} \\
\hline & & $\mathrm{Cu}$ & $\mathrm{Ni}$ & $\mathrm{Fe}$ & Mo & $\mathrm{U}_{3} \mathrm{O}_{8}$ & $\mathrm{Cu}$ & $N i$ & $\mathrm{Fe}$ \\
\hline $\begin{array}{l}+210 \\
-210+105 \\
-105+75 \\
-75+53 \\
-53\end{array}$ & $\begin{array}{l}18.9 \\
26.1 \\
7.70 \\
8.60 \\
38.7\end{array}$ & $\begin{array}{c}0.162 \\
0.087 \\
0.137 \\
0.170 \\
0.17\end{array}$ & $\begin{array}{c}0.110 \\
0.117 \\
0.135 \\
0.220 \\
0.25\end{array}$ & $\begin{array}{l}4.88 \\
5.97 \\
7.33 \\
7.98 \\
8.60\end{array}$ & $0.08^{\#}$ & & $\begin{array}{c}100 \\
78.7 \\
63.0 \\
55.7 \\
45.6\end{array}$ & $\begin{array}{c}100 \\
88.1 \\
70.9 \\
65.1 \\
54.5\end{array}$ & $\begin{array}{r}100 \\
86.9 \\
64.9 \\
56.9 \\
47.2\end{array}$ \\
\hline Head (calc) & 100 & 0.144 & 0.177 & 7.05 & 0.048 & 0.058 & 100 & 100 & 100 \\
\hline
\end{tabular}

* Mo content in the $-300+75 \mu \mathrm{m}$ fraction

\# Mo content in the $-75 \mu \mathrm{m}$ fraction

TABLE IV Assay and distribution of $\mathrm{U}_{3} \mathrm{O}_{8}$ in magnetic products (cof material)

\begin{tabular}{lccc}
\hline Products & $W t(\%)$ & $U_{3} O_{8}(\%)$ & $\begin{array}{c}\text { Distribution (\%) } \\
U_{3} O_{8}\end{array}$ \\
\hline Magnetic & 37.3 & 0.098 & 63.0 \\
Middling & 8.0 & 0.076 & 10.5 \\
Non-magnetic & 54.7 & 0.028 & 26.5 \\
Head (calc) & 100 & 0.05795 & 100 \\
\hline
\end{tabular}

\section{FLOTATION STUDIES}

In order to improve the recoveries of $\mathrm{Cu}, \mathrm{Ni}$ and $\mathrm{Mo}$ in the bulk flotation stage, it was considered essential to introduce the xanthates as collectors in place of cresylic acid. All the flotation experiments were carried out in Denver D-12 sub-aeration flotation cell at $1500 \mathrm{rpm}$ using tap water of $\mathrm{pH}$ 5.8. Sodium isopropyl xanthate, potassium amyl xanthate and aero promoter 194 (alkyldithiophosphate) were used as collectors while pine oil and MIBC were used as frothers. The as-received sample was subjected to flotation with various reagents and the details pertaining to these investigations were communicated for publication [2]. The assay of the flotation products and the distribution of $\mathrm{Cu}, \mathrm{Ni}, \mathrm{Mo}$ and $\mathrm{U}_{3} \mathrm{O}_{8}$ in these products are given in Table $\mathrm{V}$.

\section{CHARACTERISATION OF THE FLOTATION TAILINGS}

The bulk flotation tailings obtained during optimisation studies with various collectors were preserved and a sub-sample was subjected to 
TABLE V Typical bulk flotation results of the uranium ore

\begin{tabular}{|c|c|c|c|c|c|c|c|c|c|}
\hline \multirow{2}{*}{$\begin{array}{l}\text { Flotation } \\
\text { products }\end{array}$} & \multirow[t]{2}{*}{$W t \%$} & \multicolumn{4}{|c|}{ Assay, (\%) } & \multicolumn{4}{|c|}{ Distribution $(\%)$} \\
\hline & & $\mathrm{Cu}$ & $\mathrm{Ni}$ & Mo & $U_{3} O_{8}$ & $\mathrm{Cu}$ & $N i$ & Mo & $U_{3} O_{8}$ \\
\hline $\begin{array}{l}\text { Concentrate } \\
\text { Tailing }\end{array}$ & $\begin{array}{r}6 \\
94\end{array}$ & $\begin{array}{l}2.20 \\
0.0062\end{array}$ & $\begin{array}{l}1.30 \\
0.0273\end{array}$ & $\begin{array}{l}0.585 \\
0.0134\end{array}$ & $\begin{array}{l}0.12 \\
0.054\end{array}$ & $\begin{array}{r}95.8 \\
4.2\end{array}$ & $\begin{array}{l}75.3 \\
24.7\end{array}$ & $\begin{array}{l}73.6 \\
26.4\end{array}$ & $\begin{array}{l}12.4 \\
87.6\end{array}$ \\
\hline Head (calc) & 100 & 0.1378 & 0.1036 & 0.0477 & 0.058 & 100 & 100 & 100 & 100 \\
\hline
\end{tabular}

TABLE VI $\mathrm{U}_{3} \mathrm{O}_{8}$ distribution in various size fractions of the bulk flotation tailings

\begin{tabular}{lccc}
\hline Size $(\mu \mathrm{m})$ & $W t \%$ & $U_{3} O_{8}(\%)$ & $\begin{array}{c}\text { Distribution }(\%) \\
U_{3} O_{8}\end{array}$ \\
\hline+45 & 63 & 0.040 & 46.5 \\
+20 & 24.3 & 0.041 & 18.4 \\
-20 & 12.7 & 0.150 & 35.1 \\
Head (calc) & 100 & 0.0542 & 100 \\
\hline
\end{tabular}

wet screening into various size fractions and all the size fractions were analysed for $\mathrm{U}_{3} \mathrm{O}_{8}$ (Table VI).

\section{Magnetic Separation Studies}

The bulk flotation tailings were subjected to wet magnetic separation by using SALA wet low intensity magnetic separator. Around $3 \%$ by weight of the magnetic fraction could be obtained which is the magnetite present in the sample. The tailings were classified into $+100 \mu \mathrm{m}$ and $-100 \mu \mathrm{m}$ fractions and each size fraction was treated on BOXMAG wet high intensity magnetic separator at the intensity of $18,000 \mathrm{G}$. All the magnetic and non-magnetic products were analysed for $\mathrm{U}_{3} \mathrm{O}_{8}$ (Table VII).

The non-magnetic fraction obtained on the BOXMAG magnetic separator was further wet screened into $+20 \mu \mathrm{m}$ and $-20 \mu \mathrm{m}$ size fractions and both fractions were analysed for $\mathrm{U}_{3} \mathrm{O}_{8}$. (Table VIII).

\section{DISCUSSION}

The general flowsheet of uranium recovery plant (Fig. 1) at Jaduguda treats around $900 \mathrm{t} /$ day ore, assaying $0.06-0.10 \% \mathrm{Cu}, 0.08-0.10 \% \mathrm{Ni}$, 
TABLE VII Assay and distribution of $\mathrm{U}_{3} \mathrm{O}_{8}$ in classified magnetic products

\begin{tabular}{lccccc}
\hline Size $(\mu \mathrm{m})$ & Wt $\%$ & Products & $W t \%$ & $U_{3} O_{8}(\%)$ & $\begin{array}{c}\text { Distribution }(\%) \\
U_{3} O_{8}\end{array}$ \\
\hline+100 & & & & & 41.37 \\
& 45 & Magnetic & 18.36 & 0.1193 & 18.11 \\
-100 & \multirow{2}{*}{55} & Non-magnetic & 26.64 & 0.036 & 31.31 \\
& & Magnetic & 20.24 & 0.0819 & 9.19 \\
Head (calc) & \multirow{2}{*}{100} & Non-magnetic & 34.76 & 0.014 & 100 \\
& & & 100 & 0.05293 & 72.68 \\
& & Combined magnetics & 38.6 & 0.0996 & 27.32 \\
\hline
\end{tabular}

TABLE VIII Uranium distribution in the $+20 \mu \mathrm{m}$ and $-20 \mu \mathrm{m}$ fractions of the nonmagnetic product of the bulk flotation tailings

\begin{tabular}{lccc}
\hline Size $(\mu \mathrm{m})$ & $W t \%$ & $U_{3} O_{8}(\%)$ & $\begin{array}{c}\text { Distribution }(\%) \\
U_{3} O_{8}\end{array}$ \\
\hline+20 & 90 & 0.0066 & 28 \\
-20 & 10 & 0.150 & 72 \\
Head (Calc) & 100 & 0.0209 & 100 \\
\hline
\end{tabular}

$0.02-0.045 \%$ Mo and $0.045-0.06 \% \mathrm{U}_{3} \mathrm{O}_{8}$, by grinding the ore to a flotation feed size of around $67 \%$ passing $75 \mu \mathrm{m}$. After recovering the sulphide bearing minerals $\mathrm{Cu}, \mathrm{Ni}$ and $\mathrm{Mo}$ as bulk concentrate as per the flowsheet (Fig. 2) the bulk flotation tailings which are around $95 \%$ of the flotation throughput are subjected to thickening followed by acid leaching to recover the uranium values. The leach residue is treated by three permanent rotary magnets to recover magnetite as another by-product which is being supplied to coal washeries. As the sulphide minerals are less than $2 \%$ by weight in the ore the bulk flotation tailings are to be more than $95 \%$ of the plant throughput as the feed material for the uranium leaching circuit.

The assay of the classifier overflow sample revealed that the $\mathrm{Cu}, \mathrm{Ni}$ and Mo values are slightly on a higher side than the usual feed assay as can be seen from the Table III. The sample was also found to be coarse in size as it contains around $45 \%$ by weight particles coarser than $100 \mu \mathrm{m}$ size containing around $37 \% \mathrm{Cu}, 30 \% \mathrm{Ni}$ and $35 \% \mathrm{Fe}$ values in it.

The flotation studies on this classifier overflow sample, containing $0.13 \% \mathrm{Cu}, 0.14 \% \mathrm{Ni}$ and $0.045 \% \mathrm{Mo}$ (Table III) collected from the plant, with various collectors in place of cresylic acid showed that by a combination of amyl xanthate and aero promoter 194 as collector and 
MIBC as frother, the overall recoveries of $\mathrm{Cu}, \mathrm{Ni}$ and Mo could be increased substantially. From Table $\mathrm{V}$ it can be seen that the bulk concentrate contains $0.12 \% \mathrm{U}_{3} \mathrm{O}_{8}$ with $12 \%$ recovery.

The bulk flotation tailings, which are around $94 \%$ by weight, containing the remaining $88 \%$ uranium values are the eventual feed to the acid leaching circuit as per the commercial flowsheet (Fig. 1). The size and $\mathrm{U}_{3} \mathrm{O}_{8}$ analysis of the bulk flotation tailings indicate (Table VI) that nearly $35 \%$ of the uranium values are present in the finer $(-20 \mu \mathrm{m})$ fraction containing $0.15 \% \mathrm{U}_{3} \mathrm{O}_{8}$.

Magnetic separation studies on the classifier overflow sample with SALA wet low intensity drum magnetic separator indicated that around 3 to $4 \%$ of the material could be recovered as magnetite. From Table IV it can be seen that nearly $45 \%$ of the COF material is magnetic when separated on BOXMAG wet high intensity magnetic separator (at $18,000 \mathrm{G}$ ) and contains $73 \%$ of the uranium values. Prompted by such indication the magnetic separation studies were carried out on wet high intensity magnetic separator on the bulk flotation tailings after classifying them into $+100 \mu \mathrm{m}$ and $-100 \mu \mathrm{m}$ fractions. From the results of the magnetic separation studies (Table VII) it is interesting to note that $41 \%$ of the uranium values could be recovered from the $+100 \mu \mathrm{m}$ fraction assaying $0.12 \% \mathrm{U}_{3} \mathrm{O}_{8}$ as compared to $31 \%$ uranium recovery from the $-100 \mu \mathrm{m}$ fraction assaying $0.082 \% \mathrm{U}_{3} \mathrm{O}_{8}$. The $\mathrm{U}_{3} \mathrm{O}_{8}$ content in the combined magnetic fraction, of both the size fractions, was found to contain around $0.10 \% \mathrm{U}_{3} \mathrm{O}_{8}$. This led to conclude that nearly $73 \%$ of the uranium values could be recovered from the bulk flotation tailings by resorting to magnetic separation at around $18,000 \mathrm{G}$ besides enriching the uranium content to $0.10 \% \mathrm{U}_{3} \mathrm{O}_{8}$.

Although the majority of the uranium values could be recovered by introducing magnetic separation, the non-magnetic fraction still contains $27 \%$ of the uranium values assaying $0.0235 \% \mathrm{U}_{3} \mathrm{O}_{8}$. From Table VIII it is interesting to note that most of the uranium values ( $72 \%$ of the values present) are in the $-20 \mu \mathrm{m}$ size material containing $0.15 \% \mathrm{U}_{3} \mathrm{O}_{8}$ while the fraction coarser than $20 \mu \mathrm{m}$ contains only $0.0066 \% \mathrm{U}_{3} \mathrm{O}_{8}$. This indicates that by adopting an efficient desliming method the minimum assay of the $\mathrm{U}_{3} \mathrm{O}_{8}$ in the coarse fraction can be restricted to around $0.0066 \% \mathrm{U}_{3} \mathrm{O}_{8}$ on the sample studied.

As the non-magnetic fraction contains around $10 \%$ by weight of fine material $(-20 \mu \mathrm{m})$ containing $0.15 \% \mathrm{U}_{3} \mathrm{O}_{8}$, the recovery of such fines 
by means of hydrocyclone should not be problem although the efficiency of the fines separation depends on the dilution and overall size distribution of the non-magnetic fraction of the bulk flotation tailings. The details about the magnetic separation on the flotation tailings are communicated for filing patent [3]. Taking all the above aspects into consideration, the necessary modifications in the existing flowsheet to recover uranium were suggested with typical material balance in Fig. 3. It is interesting to notice that by adopting the above suggestions in the flowsheet only $42 \%$ of the bulk flotation tailings containing around $0.10 \% \mathrm{U}_{3} \mathrm{O}_{8}$ need to be processed as against $95 \%$ of the material being handled in the commercial circuit. However, the values projected in the flowsheet 3 should be taken only as indicative as these investigations were carried out on laboratory scale and the sample seems to be relatively coarser in size than the normal plant feed size.

The adoptability of these modifications in the plant are, subject to the reproducibility of achieving the disposable coarse non-magnetic fraction (cyclone underflow) with minimum of the uranium concentration meeting the restrictions imposed.

These modifications in the circuit also reduce substantially the load on the magnetite recovery plant as the magnetite reports to the magnetic fraction.

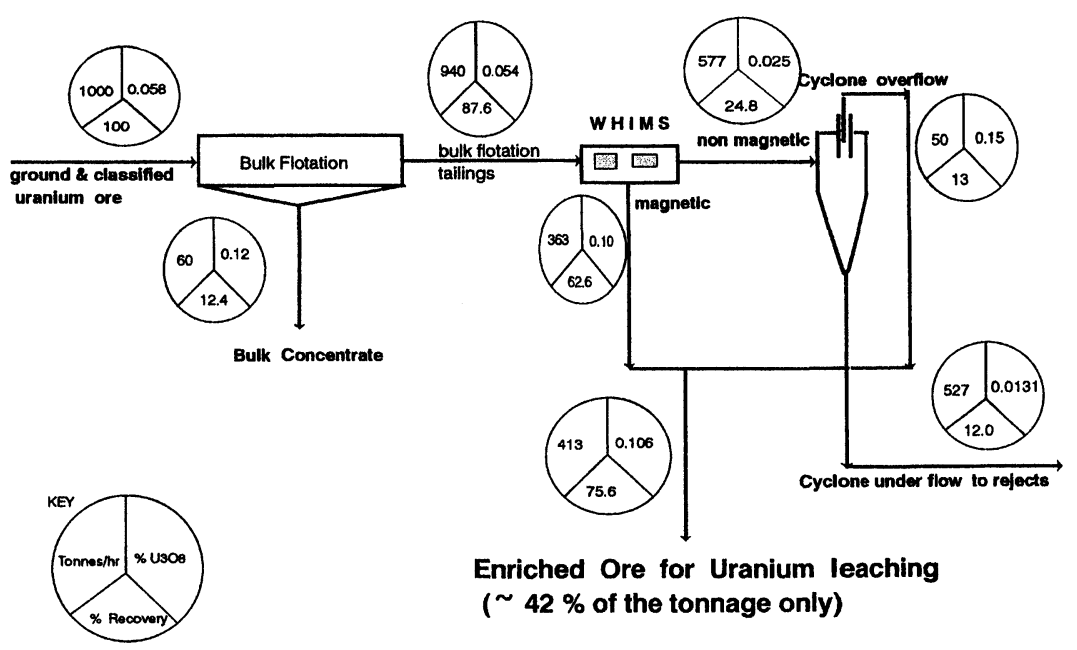

FIGURE 3 Modified flowsheet to recover uranium values with typical material balance. 


\section{CONCLUSIONS}

The uranium recovery plant at Jaduguda currently treats around $95 \%$ of the plant throughput, containing around $0.05 \% \mathrm{U}_{3} \mathrm{O}_{8}$, in the acid leaching circuit to recover the uranium values.

The laboratory investigations reveal that around $63 \%$ of the uranium values from the bulk flotation tailings can be recovered into the magnetic fraction, containing $0.1 \% \mathrm{U}_{3} \mathrm{O}_{8}$, by treating on wet high intensity magnetic separator.

The rest of the uranium values present in the non-magnetic fraction were found distributed predominantly in the $-20 \mu \mathrm{m}$ fraction.

As the combined magnetic fraction and the deslimed fines are around $42 \%$ of the plant throughput, the eventual feed to magnetite recovery and to uranium leaching circuit are only less than half of the current plant throughput.

The necessary steps to be introduced in the current commercial plant flowsheet are suggested with typical material balance.

\section{Acknowledgements}

The authors are thankful to Prof. H.S. Ray, Director, Regional Research Laboratory for permitting this paper for publication. The authorities of UCIL are duly acknowledged for arranging the necessary samples and analytical support. The assistance of Sri A.R. Prasad in carrying out the flotation studies and magnetic separation studies are duly acknowledged.

\section{References}

[1] D.V. Bhatnagar Uranium hydro metallurgy at Jaduguda. In: SERC Seminar Volume on Hydrometallurgical Process at UCIL, Jaduguda, Oct. 31-Nov. 1, 1980.

[2] G.V. Rao and L.D. Besra Enhancement of $\mathrm{Cu}, \mathrm{Ni}$ and $\mathrm{Mo}$ recoveries in the by-product recovery plant of UCIL at Jaduguda, India. (Submitted for publication.)

[3] G.V. Rao, S. Prakash and A. Raviprasad A process for the beneficiation of uranium ore (patent application). 


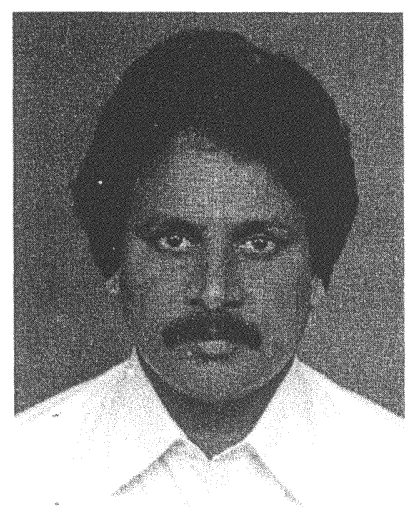

G.V. Rao is the senior scientist at Regional Research Laboratory, Bhubaneswar, India. He has one year teaching and 18 years research experience in the field of mineral processing. Mr. Rao received his B. Tech. (Chem. Engg.) and M.Sc. (Mineral Processing Engineering) degrees from Andhra University, College of Engineering, Visakhapatnam, India, and has published around 30 articles in various national and international journals.

S. Prakash obtained his M.A.Sc. degree from the Department of Mineral Processing at Sandur, Karnataka, in 1982. He has been working as a scientist at the Regional Research Laboratory, Bhubaneswar, in the field of mineral processing since 1982. Mr. Prakash published around 25 papers in various national and international journals. 